\title{
Efficacy of AST-120 in Preventing the Progression of Chronic Kidney Disease: A Meta-analysis
}

\author{
Vernon Chuabio ${ }^{1}$, Ron Castillo ${ }^{1}$, Jereel Sahagun ${ }^{1}$, and Rey Jaime Tan ${ }^{1}$ \\ ${ }^{1}$ Philippine General Hospital
}

November 19, 2020

\begin{abstract}
Chronic kidney disease (CKD) is a major cause of disease burden globally. With end-stage renal disease (ESRD), renal replacement therapy via dialysis or kidney transplant can be economically costly. This meta-analysis evaluated the efficacy of AST-120, an oral adsorbent marketed to be able to delay progression of CKD. Outcomes assessed included mortality, ESRD incidence, and doubling of serum creatinine. Databases including Cochrane, PubMed, and Clinicaltrials.gov were searched, and literature-mining from prior publications was also done, yielding a total of 50 non-duplicate citations. Further screening for appropriateness yielded 5 studies included in this meta-analysis. Regarding the effect of AST-120 on all-cause mortality among CKD patients, the pooled data showed a total of 110 events out of 1503 subjects in the interventional group and 116 events out of 1494 subjects in the control group, giving a risk ratio (RR) with $95 \%$ confidence interval (CI) of 0.94 [0.74, 1.21]. On the outcome of ESRD incidence, a total of 353 events out of 1524 subjects in the interventional group and 374 events out of 1517 subjects in the control group yielded a RR with $95 \%$ CI of 0.94 [0.83, 1.07]. Regarding doubling of serum creatinine, 155 events in both the interventional and control groups, which had 1503 and 1494 subjects, respectively, gave a RR with $95 \%$ CI of 0.99 $[0.80,1.22]$. In conclusion, AST-120 has no significant clinical benefit over standard treatment in delaying CKD progression. Further studies examining different dosages of AST-120 and its effect on different CKD stages are recommended.
\end{abstract}

Efficacy of AST-120 in Preventing the Progression of Chronic Kidney Disease: A Meta-analysis Vernon A. Chuabio ${ }^{1}$

Ron Michael L. Castillo ${ }^{1}$

Jereel R. Sahagun ${ }^{1}$

Rey Jaime M. Tan ${ }^{1,2}$

${ }^{1}$ Department of Medicine, Philippine General Hospital, University of the Philippines Manila

${ }^{2}$ Division of Nephrology, Department of Medicine, Philippine General Hospital, University of the Philippines Manila

\section{DISCLOSURES}

All the authors report no conflicts of interest in the pursuit of this study.

Postal address:

Taft Avenue, Ermita, Manila, Metro Manila, Philippines 1000

Telephone number:

(632) 8554-8400 
Email address:

vachuabio@up.edu.ph

\section{ABSTRACT}

Chronic kidney disease (CKD) is a major cause of disease burden globally. With end-stage renal disease (ESRD), renal replacement therapy via dialysis or kidney transplant can be economically costly. This metaanalysis evaluated the efficacy of AST-120, an oral adsorbent marketed to be able to delay progression of CKD. Outcomes assessed included mortality, ESRD incidence, and doubling of serum creatinine.

Databases including Cochrane, PubMed, and Clinicaltrials.gov were searched, and literature-mining from prior publications was also done, yielding a total of 50 non-duplicate citations. Further screening for appropriateness yielded 5 studies included in this meta-analysis.

Regarding the effect of AST-120 on all-cause mortality among CKD patients, the pooled data showed a total of 110 events out of 1503 subjects in the interventional group and 116 events out of 1494 subjects in the control group, giving a risk ratio (RR) with $95 \%$ confidence interval (CI) of 0.94 [0.74, 1.21]. On the outcome of ESRD incidence, a total of 353 events out of 1524 subjects in the interventional group and 374 events out of 1517 subjects in the control group yielded a RR with 95\% CI of 0.94 [0.83, 1.07]. Regarding doubling of serum creatinine, 155 events in both the interventional and control groups, which had 1503 and 1494 subjects, respectively, gave a RR with $95 \%$ CI of 0.99 [0.80, 1.22].

In conclusion, AST-120 has no significant clinical benefit over standard treatment in delaying CKD progression. Further studies examining different dosages of AST-120 and its effect on different CKD stages are recommended.

Keywords: AST 120, chronic kidney failure, creatinine, disease progression, renal dialysis

\section{REVIEW CRITERIA}

Various databases were searched in addition to reviewing previously published literature on the topic. Articles were selected for inclusion in the meta-analysis based on satisfaction of containing the intervention and outcomes of interest. Pooled data obtained from the included studies were synthesized using statistical software to generate pooled results subsequently analyzed.

\section{MESSAGE FOR THE CLINIC}

Though some studies and reviews have suggested the efficacy of the oral adsorbent AST-120 in delaying progression of $\mathrm{CKD}$, this meta-analysis did not find significant benefit over conventional treatment in terms of clinically important outcomes. Hence, the use of AST-120 for the purpose of delaying CKD progression does not appear to be evidence-based practice as of this time.

\section{INTRODUCTION}

\section{Background}

Chronic kidney disease (CKD), defined as kidney damage or decreased kidney function for three or more months, is one of the leading causes of morbidity and mortality worldwide. ${ }^{1,2}$ It is associated with increased risk for cardiovascular events, frequent hospitalization, and death. ${ }^{3,4,5}$ For end-stage renal disease, the management is renal replacement therapy through dialysis or kidney transplantation. Locally, in 2017, hemodialysis ranked as the top procedure with the Philippine Health Insurance Corporation (PhilHealth) paying a total of Php 8.4 billion worth of claims. ${ }^{6}$

Oral adsorbents, like AST-120, are substances that bind biologically active compounds, such as uremic toxins, in the gastrointestinal tract. Through binding and eventual excretion, they minimize the accumulation of these toxins in the body. The levels of uremic toxins, such as indoxyl sulfate and $p$-cresyl sulfate, in the body have been shown to be associated with progression of CKD, increased cardiovascular risk, and 
mortality. ${ }^{7,8,9,10}$ Worsening CKD will in turn result in production of more uremic toxins leading to a vicious cycle.

AST-120 has been shown to decrease serum levels of indoxyl sulfate in rats ${ }^{11,12}$ and delay progression of CKD in animals with reduced kidney mass. ${ }^{13,14}$ Currently, based on several studies, ${ }^{15,16,17}$ some of its suggested clinical utilities among patients with chronic kidney disease (CKD) is to reduce uremic symptoms and delay the progression to renal replacement therapy and kidney transplantation.

\section{Importance and Implications}

Currently, the use of AST-120 in the management of CKD is not yet included in clinical practice guidelines due to the paucity of large-scale trials. The most recent systematic reviews and meta-analyses are based on several small studies with a relatively small population size. With the recent publication of three large clinical trials, namely EPPIC-1, EPPIC-2, and K-STAR, there was a need to consolidate evidence regarding the efficacy of AST-120 in preventing progression of CKD.

\section{Research Question}

Among adult patients with chronic kidney disease (CKD), how effective is oral adsorbent AST-120 in delaying the progression to end-stage renal disease (ESRD)?

\section{Objectives}

1. To determine the effect of oral adsorbent AST-120 in the incidence of dialysis in patients with CKD

2. To determine the effect of oral adsorbent AST-120 in the incidence of kidney transplantation in patients with CKD

3. To determine the effect of AST-120 in mortality among patients with CKD

4. To determine the effect of AST-120 in serum creatinine and creatinine clearance among patients with CKD

METHODOLOGY

\section{INCLUSION CRITERIA}

\section{Study Design}

All prospective controlled trials evaluating the use of AST-120 in preventing ESRD or delaying the progression of CKD were included. Non-prospective controlled studies were excluded from this systematic review.

\section{Participants}

We included studies with adult participants with CKD (stages 1 to 4 ) and those with CKD stage 5 not on dialysis or kidney transplantation, regardless of sex, age, and etiology of CKD. The definition and staging of CKD were based on the KDOQI (2002) and KDIGO (2013) criteria.

\section{Interventions}

Studies evaluating the use of oral adsorbent AST-120 in addition to routine treatment in delaying the progression of CKD or preventing ESRD were included, regardless of dosage or duration of treatment.

\section{Comparators}

The comparator was placebo in addition to routine treatment. Routine treatment included control of CKD risk factors, such as diabetes mellitus and hypertension, and management of complications. These included, but were not limited to, blood pressure control, glycemic control and diet control.

\section{Outcomes}

Primary Outcomes

1. Incidence of all-cause mortality 
2. Incidence of end-stage renal disease

3. Incidence of doubling of serum creatinine

Secondary Outcomes

Incidence of adverse events

\section{Language}

Relevant studies written in English were included. We included studies written in other languages provided that translated copies in English were obtained.

\section{INFORMATION SOURCES}

\section{Search Strategy}

In this review, we searched for prospective controlled trials determining the efficacy of the oral adsorbent AST-120 in delaying the decline of renal function among CKD patients, regardless of etiology. In terms of outcomes, articles with any one of the following outcomes were deemed appropriate for inclusion in the review: rate of serum creatinine increase, rate of deterioration of creatinine clearance, incidence of dialysis, incidence of kidney transplantation, adverse events or mortality rate.

We searched for articles in PubMed including MedLine, Clinicaltrials.gov, and Cochrane databases. Search terms were based on the components of the research question. Keywords used were as follows: "chronic kidney disease," serving as the concept for the population, and "oral adsorbent," serving as the concept for the intervention. In the process of using the databases' search engines, each of these concepts were expanded using Boolean operators to maximize search sensitivity. The term "chronic kidney disease" were combined with its alternative terms, including its MeSH terms, using the "OR" Boolean operator. The term "oral adsorbent" were likewise combined with its alternative term ("Kremezin") and MeSH counterpart ("AST120"). These expanded concepts for the population and intervention were intersected using the "AND" Boolean operator to narrow down the search. The retrieved articles were further filtered to only include prospective controlled trials. Each of the abstracts of the articles were examined to assess appropriateness for inclusion in the meta-analysis. Articles that did not reflect the research question, as well as studies that were not prospective controlled trials, were excluded.

Specifically, the search entailed the use of the following terms: ("chronic kidney disease"[All Fields] OR "chronic renal disease"[All Fields] OR "chronic renal failure" [All Fields] OR "chronic kidney failure"[All Fields] OR "chronic renal insufficiency"[MeSH Terms]) AND ("oral adsorbent"[All Fields] OR "Kremezin" [All Fields] OR "AST-120" [MeSH Terms])

\section{Selection of Studies}

Two reviewers independently searched the literature using the predetermined search criteria and strategy. Subsequently, the reviewers also independently determined the trials for inclusion in the meta-analysis. Any conflict in the process were resolved by another reviewer. The flow of selection of studies was shown using the Preferred Reporting Items for Systematic Reviews and Meta-analyses (PRISMA) diagram. For articles that were not in English language, the authors of the studies in question were contacted for English languagetranslated copies, if available. English language-translated copies of the studies were in the systematic review.

\section{Data Collection, Risk of Bias Assessment, and Data Analyses}

The reviewers independently extracted data from the included studies using a standardized data collection form based on RevMan v5.3. More specifically, the following data were extracted: inclusion and exclusion criteria of the study population, age, sex, recruitment, follow up, intervention and control, and outcomes of interest. In cases where study data are deemed unclear or ambiguous, study authors were contacted for clarifications. 
In assessing included studies for bias, the Cochrane Collaboration Tool Risk of Bias Tool were used to evaluate the following: randomization method, method of allocation concealment, attrition bias, blinding of both study subjects and personnel, blinding of outcome assessors, intention-to-treat analysis, and other biases. The RevMan v5.3 software was used to analyze the data extracted from the studies. Depending on the available collective data, prespecified subgroup analyses as stated in the objectives of the meta-analysis were done. Forest plot analyses were used to demonstrate the magnitude of treatment effects in terms of the outcomes of interest. Heterogeneity testing using $\mathrm{I}^{2}$, Chi-square tests, were also accomplished

\section{RESULTS}

\section{Literature Search}

We searched for articles in the PubMed (includes Medline), Cochrane Library, and Clinicaltrials.gov databases up until September 2019. We also did literature mining from a pertinent systematic review. With these strategies, a total of 50 articles were retrieved after taking into account duplicates. After screening these 50 non-duplicate articles using the inclusion and exclusion criteria, 37 articles were excluded. The full texts of 13 remaining citations were then reviewed to assess appropriateness for inclusion in the metaanalysis, where in the process, 8 articles were excluded. Thus, only 5 citations were finally included for pooling in the meta-analysis. The PRISMA diagram summarizing the results of the search strategy is shown inFigure 1 . The characteristics of the 5 studies based on the following parameters are shown in Table 1 : General Details, Inclusion Criteria, Exclusion Criteria, Intervention, and Outcomes.

\section{Included Studies}

Five randomized-controlled studies were included. One (Schulman, 2015) was placebo-controlled while the rest (Akizawa, 2009; Cha, 2016; Konishi, 2008; Yorioka, 2008) were open-label studies comparing AST-120 plus routine treatment versus routine treatment alone. The EPPIC- 1 and EPPIC-2 trials are combined in the Schulman 2015 study.

\section{Risk of Bias Assessment}

As previously mentioned, the Cochrane Collaboration Risk of Bias Tool was used to assess validity of the citations included in the meta-analysis. Areas assessed included method of randomization and allocation concealment, blinding, and attrition rate. Figure 2summarizes the results of the risk of bias assessment.

Although all five studies were randomized controlled trials, only three (Cha, 2016; Konishi, 2008; Schulman, 2015) were clear in the method of randomization, while only one (Cha, 2016) was clear in the method of allocation concealment. Only one (Schulman, 2015) was able to blind participants and outcome assessors by having a placebo preparation. However, given that the main outcomes of interest in the meta-analysis are objective, dichotomous outcomes, the failure to blind would not seem to significantly affect the results. In effect, all the included studies were deemed to have low risk of bias in terms of blinding of outcome assessment. As for attrition bias and reporting bias, the majority (Akizawa, 2009; Konishi, 2008; Schulman, 2015) of the studies had low risk of bias.

\section{Outcomes}

In pooling the included studies, the effect of AST-120 on the following primary outcomes was determined: mortality, incidence of ESRD (initiation of renal replacement therapy), and doubling of serum creatinine. The effect of AST-120 on the secondary outcomes of interest were not evaluated due to the paucity of data in the retrieved clinical trials. Likewise, the intended analyses on the prespecified subpopulations were forgone due to the lack of pertinent data in the included studies.

In terms of the outcome of all-cause mortality, four trials were pooled, with a resulting total population size of 1503 in the interventional group and 1494 in the control group. There were a total of 110 mortalities in the interventional group and 116 mortalities in the control group, yielding a risk ratio (RR) and $95 \%$ confidence interval (CI) of $0.94[0.74,1.21]$. This finding suggests that AST-120, compared to standard treatment, has 
no effect on the outcome of mortality among patients with CKD. The Forest plot for this primary outcome is shown in Figure 3 .

Regarding the effect of AST-120 on the initiation of RRT, the pooled data shows that there were 353 events out of a total sample size of 1524 in the interventional group while there 374 events out of a total population of 1517 in the control group. This gives a risk ratio with $95 \%$ CI of $0.94[0.83,1.07]$ with no heterogeneity. This finding suggests that AST-120 confers no significant benefit in preventing or delaying the incidence of ESRD or initiation of RRT among adults with CKD (Figure 4) .

Lastly, in terms of the effect of AST-120 on the doubling of serum creatinine, four trials were pooled, giving a total population of 1503 in the interventional group and 1494 in the control group. There were a total of 155 incidences of doubling of serum creatinine in the AST-120 group and also 155 incidences in the control group. This yields a risk ratio with $95 \%$ CI of $0.99[0.80,1.22]$ with no heterogeneity, suggesting that AST-120 has no significant effect on the outcome of doubling of serum creatinine (Figure 5 ).

Pooled analysis on the adverse events associated with AST-120 cannot be generated from the studies included in this review due to inadequate recording and differences in reporting of adverse events. In general, usual adverse effects reported in the studies are gastrointestinal in nature.

\section{DISCUSSION}

This review aimed to determine if AST-120 is effective in delaying the progression of CKD by measuring outcomes including incidence of all-cause mortality, incidence of ESRD requiring renal replacement therapy, and doubling of serum creatinine. Results showed that there is no significant difference in the incidences of the three primary endpoints between patients given AST-120 and those given routine treatment alone.

Despite the current availability of a commercially-marketed preparation of AST-120, the results obtained in this meta-analysis do not support its use for the purpose of preventing death or delaying the time to initiation of ESRD among patients with CKD. Some trials could have shown an advantage of using AST-120 in terms of slowing the rate of increase in serum creatinine among CKD patients; however, this outcome is clinically insignificant since the levels of serum creatinine alone are not the sole determinant of overall well-being in actual clinical settings. Thus, the finding of dampened increase in the rate of serum creatinine with the use of AST-120 does not justify its use among patients with CKD. It would be more meaningful to assess the benefit of using AST-120 in terms of its effect on clinically significant outcomes such as mortality and incidence of RRT.

Several factors may have contributed to the lack of significant effects of AST-120. First is the possibility of advanced disease in many participants (as evidenced by a significant percentage reaching the primary outcome) that may not be effectively altered or reversed by AST-120 anymore. Second, the varying dosages of AST-120 used in different studies may have contributed to the wide range of results. The incidence of adverse effects, though reported in several studies, were not pooled and analyzed due to differences in reporting of these data.

Despite the insignificant findings in this meta-analysis, other areas regarding the potential beneficial use of AST-120 may still be explored. For future studies, it might be helpful to stratify study populations based on the dose of AST-120, as there could be a potential dose-dependent clinical benefit in using AST-120 after all. Also, stratification based on stage of CKD may also be done, as the magnitude of the effect of AST-120 may be dependent on CKD stage. It could be possible that the use of AST-120 might after all be clinically advantageous when initiated at the earlier stages of CKD.

\section{CONCLUSION}

Based on the pooled data obtained in this meta-analysis, it can be concluded that among adults with CKD, the oral adsorbent AST-120 offers no significant advantage over standard treatment in terms of reducing the incidence of mortality, ESRD, and doubling of serum creatinine. Further studies examining different dosages of AST-120 and its effect on different CKD stages are recommended. 


\section{AUTHOR CONTRIBUTIONS}

All the listed authors contributed significantly to this study. Vernon A. Chuabio and Ron Michael L. Castillo prepared the study protocol, searched the literature, pooled the retrieved data, synthesized results using statistical software, and drafted the article. Jereel R. Sahagun and Rey Jaime M. Tan provided revisions to the study with respect to methods, content, interpretation of results, as well as gave final approval for this study.

\section{ACKNOWLEDGEMENTS}

This study did not receive funding from any external entity, be it a personality or institution. All the authors are affiliated with the Department of Medicine of the Philippine General Hospital. We would like to acknowledge the insights and inputs by our consultant colleagues from the Division of Nephrology of our department. We would also like to thank the Clinical Research Division of our department for the technical assistance provided.

\section{REFERENCES}

1. National Kidney Foundation. KDOQI clinical practice guidelines for chronic kidney disease: evaluation, classification, and stratification. American Journal of Kidney Disease . 2002; 39(1):1-266.

2. Kidney Disease: Improving Global Outcomes (KDIGO) CKD Work Group. KDIGO 2012 clinical practice guideline for the evaluation and management of chronic kidney disease. Kidney International Supplements . 2013; 3(1):1-150.

3. Go AS, Chertow GM, Fan D, McCulloch CE, Hsu CY. Chronic kidney disease and the risks of death, cardiovascular events, and hospitalization. New England Journal of Medicine . 2004; 351:1296-1305.

4. Levey AS, Coresh J. Chronic kidney disease. Lancet . 2012; 379:165-180.

5. Romagnani P, Remuzzi G, Glassock R, Levin A, Jager KJ, Tonelli M, et al. Chronic kidney disease. Nature Reviews Disease Primers . 2017; 3:17088.

6. Philippine Health Insurance Corporation. 2017 Stats and Charts [internet]. PhilHealth . 2017. Available from https://www.philhealth.gov.ph/about_us/statsncharts/snc2017.pdf.

7. Barreto FC, Barreto DV, Liabeuf S, Meert N, Glorieux G, Temmar M, et al. European Uremic Toxin Work Group (EUTox): Serum indoxyl sulfate is associated with vascular disease and mortality in chronic kidney disease patients. Clinical Journal of the American Society of Nephrology . 2009; 4:1551-1558.

8. Liabeuf S, Barreto DV, Barreto FC, Meert N, Glorieux G, Schepers E, et al. European Uremic Toxin Work Group (EUTox): Free p-cresyl sulfate is a predictor of mortality in patients at different stages of chronic kidney disease. Nephrology Dialysis Transplantation . 2010; 25:1183-1191.

9. Meijers BK, Claes K, Bammens B, de Loor H, Viaene L, Verbeke K, et al. p-Cresol and cardiovascular risk in mild-to-moderate kidney disease.Clinical Journal of the American Society of Nephrology . 2010; 5:1182-1189.

10. Wu IW, Hsu KH, Lee CC, Sun CY, Hsu HJ, Tsai CJ, et al. p-Cresyl sulfate and indoxyl sulphate predict progression of chronic kidney disease. Nephrology Dialysis Transplantation . 2011; 26:938-947.

11. Niwa T, Yazawa T, Ise M, Sugano M, Kodama T, Uehara Y, Maeda K. Inhibitory effect of oral sorbent on accumulation of albumin-bound indoxyl sulfate in serum of experimental uremic rats. Nephron . $1991 ; 57: 84-88$.

12. Akiyama Y, Takeuchi Y, Kikuchi K, Mishima E, Yasuaki Y, Suzuki C, et al. A metabolomic approach to clarifying the effect of AST-120 on $5 / 6$ nephrectomized rats by capillary electrophoresis with mass spectrometry (CE-MS). Toxins . 2012; 4(11):1309-22.

13. Okada K, Matsumoto K, Takahashi S. Uremic toxins adsorbed by AST-120 promote tubular hypertrophy and interstitial fibrosis in nephrectomized rats. Kidney 8 Blood Pressure Research . 2005; 28(1):8-13.

14. Bolati D, Shimizu H, Niwa T. AST-120 ameliorates epithelial-to-mesenchymal transition and interstitial fibrosis in the kidneys of chronic kidney disease rats. Journal of Renal Nutrition . 2012; 22(1):176-80.

15. Konishi K, Nakano S, Tsuda S, Nakagawa A, Kigoshi T, Koya D. AST-120 (Kremezin) initiated 
in early stage chronic kidney disease stunts the progression of renal dysfunction in type 2 diabetic subjects.Diabetes Research and Clinical Practice . 2008; 81:310-315.

16. Nakamura T, Sato E, Fujiwara N, Kawagoe Y, Suzuki T, Ueda Y, Yamagishi S. Oral adsorbent AST120 ameliorates tubular injury in chronic renal failure patients by reducing proteinuria and oxidative stress generation. Metabolism . 2011; 60:260-264.

17. Hatakeyama S, Yamamoto H, Okamoto A, Imanishi K, Tokui N, Okamoto T, et al. Effect of an oral adsorbent, AST-120, on dialysis initiation and survival in patients with chronic kidney disease. International Journal of Nephrology. 2012; 376128.

FIGURE LEGENDS

Figure 1 . Study Flow Diagram.

Figure 2. Risk of Bias Summary. Each study included in the meta-analysis was assessed for risk of bias based on whether the various measures as shown in the figure were satisfied. Question marks within yellow circles indicate that it was not clear whether the study satisfied the measure. Plus signs within green circles indicate that the study satisfied the measure. Minus signs within red circles indicate that the study did not satisfy the measure. The EPPIC-1 and EPPIC-2 trials were combined under "Schulman 2015" as shown in the figure.

Figure 3. Comparison of the Effect of AST-120 versus Control on All-cause Mortality.

Figure 4. Comparison of the Effect of AST-120 versus Control on the Incidence of End-stage Renal Disease Requiring Renal Replacement Therapy.

Figure 5. Comparison of the Effect of AST-120 versus Control on Serum Creatinine Levels.

Table 1 Characteristics of Studies Included in the Meta-analysis 


\begin{tabular}{|c|c|c|c|c|c|}
\hline Study & $\begin{array}{l}\text { General } \\
\text { Details }\end{array}$ & $\begin{array}{l}\text { Inclusion } \\
\text { Criteria }\end{array}$ & $\begin{array}{l}\text { Exclusion } \\
\text { Criteria }\end{array}$ & Intervention & Outcomes \\
\hline Akizawa 2009 & $\begin{array}{l}\text { Country: Japan } \\
\text { Study design: } \\
\text { randomized } \\
\text { controlled trial } \\
\text { Number: } \\
\text { treatment group } \\
\text { (231), control } \\
\text { group ( } 229) \\
\text { Duration: } 56 \\
\text { weeks Chronic } \\
\text { kidney disease } \\
\text { stage of } \\
\text { treatment group } \\
\text { subjects: } 3 \text { or } \\
\text { lower ( } 21 \%), 4 \\
\text { (47\%), } 5 \text { ( } 32 \%) \\
\text { Chronic kidney } \\
\text { disease stage of } \\
\text { control group } \\
\text { subjects: } 3 \text { or } \\
\text { lower (20\%), } 4 \\
(53 \%), 5(27 \%)\end{array}$ & 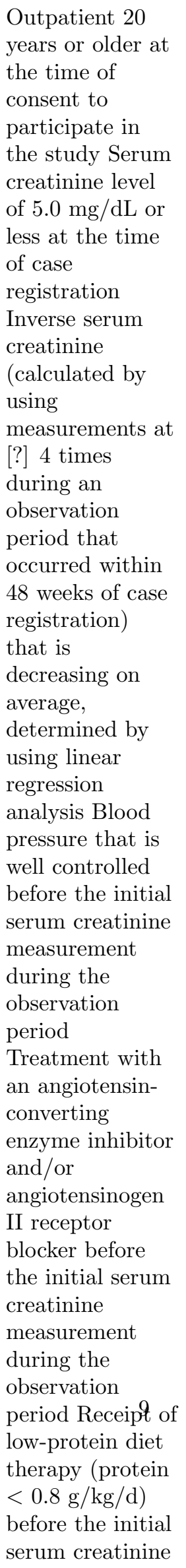 & 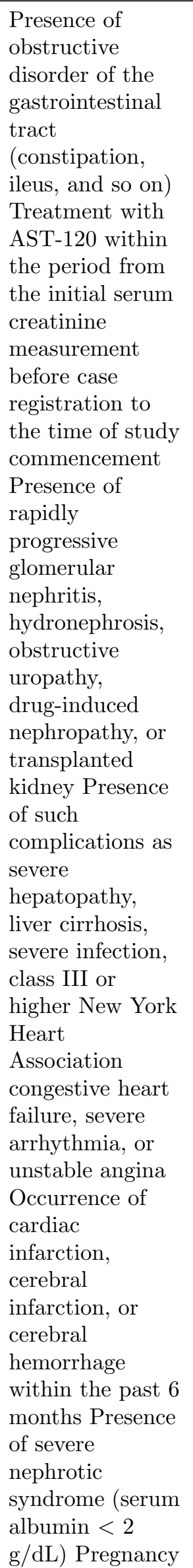 & $\begin{array}{l}\text { Treatment } \\
\text { group: AST-120 } \\
6 \text { g/d (3 divided } \\
\text { doses) + } \\
\text { conventional } \\
\text { treatment } \\
\text { Control group: } \\
\text { conventional } \\
\text { treatment } \\
\text { Conventional } \\
\text { treatment: low } \\
\text { protein diet } \\
\text { (protein < } 0.8 \\
\text { g/kg/d) + } \\
\text { angiotensin- } \\
\text { converting } \\
\text { enzyme inhibitor } \\
\text { or } \\
\text { angiotensinogen } \\
\text { II receptor } \\
\text { blocker }\end{array}$ & $\begin{array}{l}\text { Incidence of } \\
\text { end-stage renal } \\
\text { disease Mortality } \\
\text { rate Doubling or } \\
\text { serum creatinine } \\
\text { Adverse events }\end{array}$ \\
\hline
\end{tabular}




\begin{tabular}{|c|c|c|c|c|c|}
\hline Study & $\begin{array}{l}\text { General } \\
\text { Details }\end{array}$ & $\begin{array}{l}\text { Inclusion } \\
\text { Criteria }\end{array}$ & $\begin{array}{l}\text { Exclusion } \\
\text { Criteria }\end{array}$ & Intervention & Outcomes \\
\hline Cha 2016 & $\begin{array}{l}\text { Country: South } \\
\text { Korea Study } \\
\text { design: } \\
\text { randomized } \\
\text { controlled trial } \\
\text { Number: } \\
\text { treatment group } \\
\text { (289), control } \\
\text { group (290) } \\
\text { Duration: } 36 \\
\text { months Chronic } \\
\text { kidney disease } \\
\text { stage of control } \\
\text { group subjects: } \\
3 \text { (29.3\%), } 4 \\
(70.7 \%) \text { Chronic } \\
\text { kidney disease } \\
\text { stage of } \\
\text { treatment group } \\
\text { subjects: } 3 \\
(26.5 \%), 4 \\
(73.5 \%)\end{array}$ & $\begin{array}{l}\text { Provided } \\
\text { informed consent } \\
\text { Aged [?]18 years } \\
\text { Followed over } 6 \\
\text { months by } \\
\text { nephrologists } \\
\text { Chronic kidney } \\
\text { disease stage } 3 \\
\text { or } 4 \text { Expected } \\
\text { estimated } \\
\text { glomerular } \\
\text { filtration rate } \\
\text { decline of [?] } 2.5 \\
\text { ml/min per } 1.73 \\
\text { m2 over } 6 \\
\text { months or [?] } 5 \\
\text { ml/min per } 1.73 \\
\text { m2 over } 12 \\
\text { months Had } \\
\text { controlled blood } \\
\text { pressure No } \\
\text { significant } \\
\text { changes in the } \\
\text { medical } \\
\text { treatment for } \\
\text { chronic kidney } \\
\text { disease }\end{array}$ & 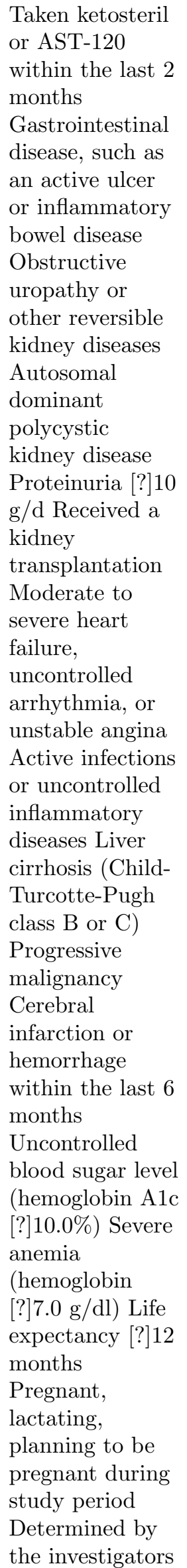 & $\begin{array}{l}\text { Treatment } \\
\text { group: AST-120 } \\
6.0 \text { g/day ( } 3 \\
\text { divided doses) + } \\
\text { routine } \\
\text { treatment } \\
\text { Control group: } \\
\text { routine } \\
\text { treatment } \\
\text { Routine } \\
\text { treatment: } \\
\text { standard care } \\
\text { including } \\
\text { angiotensin- } \\
\text { converting } \\
\text { enzyme inhibitor } \\
\text { or } \\
\text { angiotensinogen } \\
\text { II receptor } \\
\text { blocker and lipid } \\
\text { modifiers, } \\
\text { low-salt and } \\
\text { low-protein diet }\end{array}$ & $\begin{array}{l}\text { Doubling of } \\
\text { serum creatinine } \\
50 \% \text { reduction in } \\
\text { glomerular } \\
\text { filtration rate } \\
\text { End-stage renal } \\
\text { disease requiring } \\
\text { renal } \\
\text { replacement } \\
\text { therapy Urinary } \\
\text { protein excretion } \\
\text { All-cause } \\
\text { mortality } \\
\text { All-cause } \\
\text { hospitalization } \\
\text { Quality-of-life } \\
\text { assessment }\end{array}$ \\
\hline
\end{tabular}




\begin{tabular}{|c|c|c|c|c|c|}
\hline Study & $\begin{array}{l}\text { General } \\
\text { Details }\end{array}$ & $\begin{array}{l}\text { Inclusion } \\
\text { Criteria }\end{array}$ & $\begin{array}{l}\text { Exclusion } \\
\text { Criteria }\end{array}$ & Intervention & Outcomes \\
\hline Konishi 2008 & $\begin{array}{l}\text { Country: Japan } \\
\text { Study design: } \\
\text { randomized } \\
\text { controlled trial } \\
\text { Number: } \\
\text { treatment group } \\
\text { (6), control } \\
\text { group (10) Mean } \\
\text { duration of } \\
\text { follow up: } 37 \\
\text { months (control } \\
\text { group), } 34 \\
\text { months } \\
\text { (treatment } \\
\text { group) }\end{array}$ & $\begin{array}{l}\text { Persistent } \\
\text { positive test for } \\
\text { urinary protein } \\
\text { or }>300 \mathrm{mg} / \mathrm{g} \\
\text { creatinine of } \\
\text { albumin in a } \\
\text { spot urine } \\
\text { Having type } 2 \\
\text { diabetes mellitus } \\
\text { Serum creatinine } \\
<1.5 \mathrm{mg} / \mathrm{dL} \\
24 \text {-h urinary } \\
\text { protein excretion } \\
>0.5 \text { g/day No } \\
\text { history of } \\
\text { cardiovascular } \\
\text { diseases }\end{array}$ & $\begin{array}{l}\text { Those not } \\
\text { satisfying } \\
\text { inclusion criteria }\end{array}$ & $\begin{array}{l}\text { Treatment } \\
\text { group: AST-120 } \\
6.0 \mathrm{~g} / \text { day }+ \\
\text { conventional } \\
\text { treatment } \\
\text { Control group: } \\
\text { conventional } \\
\text { treatment } \\
\text { Conventional } \\
\text { treatment: blood } \\
\text { pressure, lipid, } \\
\text { glycemic control }\end{array}$ & $\begin{array}{l}\text { Incidence of } \\
\text { end-stage renal } \\
\text { disease } \\
\text { (hemodialysis } \\
\text { initiation) } \\
\text { Incidence of } \\
\text { serum creatinine } \\
\text { exceeding } 2 \\
\mathrm{mg} / \mathrm{dL}\end{array}$ \\
\hline
\end{tabular}




\begin{tabular}{|c|c|c|c|c|c|}
\hline Study & $\begin{array}{l}\text { General } \\
\text { Details }\end{array}$ & $\begin{array}{l}\text { Inclusion } \\
\text { Criteria }\end{array}$ & $\begin{array}{l}\text { Exclusion } \\
\text { Criteria }\end{array}$ & Intervention & Outcomes \\
\hline $\begin{array}{l}\text { Schulman } 2015 \\
\text { (EPPIC-1) }\end{array}$ & $\begin{array}{l}\text { Multi-center } \\
\text { Study design: } \\
\text { randomized } \\
\text { controlled trial } \\
\text { Number: } \\
\text { treatment group } \\
\text { (510), control } \\
\text { group (510) } \\
\text { Median } \\
\text { duration: } 102.1 \\
\text { weeks (treatment } \\
\text { group), 103.3 } \\
\text { weeks (control } \\
\text { group) Chronic } \\
\text { kidney disease } \\
\text { stage of subjects } \\
\text { in treatment } \\
\text { group: } 3 \text { a (1\%), } \\
\text { 3b (18.8\%), } 4 \\
\text { (62\%), } 5 \text { (18.2\%) } \\
\text { Chronic kidney } \\
\text { disease stage of } \\
\text { subjects in } \\
\text { control group: } \\
\text { 3a (0.2\%), 3b } \\
\text { (15.3\%), } 4 \\
(69.3 \%), 5 \\
\text { (15.1\%) }\end{array}$ & $\begin{array}{l}\text { Age [?]18 years } \\
\text { Moderate to } \\
\text { severe chronic } \\
\text { kidney disease } \\
\text { Proteinuria or } \\
\text { progressive } \\
\text { decline of renal } \\
\text { function } \\
\text { Expected not to } \\
\text { require renal } \\
\text { replacement } \\
\text { therapy for } 6 \\
\text { months after } \\
\text { trial Stable } \\
\text { blood pressure in } \\
\text { the past } 3 \\
\text { months }\end{array}$ & $\begin{array}{l}\text { Uncontrolled } \\
\text { hypertension } \\
\text { Obstructive or } \\
\text { reversible kidney } \\
\text { disease } \\
\text { Nephrotic } \\
\text { syndrome (urine } \\
\text { protein/urine } \\
\text { creatinine } 6.0 \text { ) } \\
\text { Adult polycystic } \\
\text { kidney disease } \\
\text { Uncontrolled } \\
\text { arrhythmia or } \\
\text { severe } \\
\text { cardiovascular } \\
\text { disease Immuno- } \\
\text { suppressive } \\
\text { therapy within } 3 \\
\text { months } \\
\text { Accelerated or } \\
\text { malignant } \\
\text { hypertension } \\
\text { within } 6 \text { months } \\
\text { History of any of } \\
\text { the following: } \\
\text { kidney } \\
\text { transplantation, } \\
\text { malabsorption, } \\
\text { inflammatory } \\
\text { bowel disease, } \\
\text { hiatal hernia, } \\
\text { active peptic } \\
\text { ulcer, and severe } \\
\text { gastrointestinal } \\
\text { dysmotility not } \\
\text { attributable to } \\
\text { the use of a } \\
\text { phosphate } \\
\text { binder }\end{array}$ & $\begin{array}{l}\text { Treatment } \\
\text { group: AST-120 } \\
9.0 \text { g/day (ten } \\
\text { 300-mg capsules } \\
\text { thrice daily with } \\
\text { meals) + routine } \\
\text { treatment } \\
\text { Control group: } \\
\text { placebo (ten } \\
\text { 300-mg capsules } \\
\text { thrice daily with } \\
\text { meals) + routine } \\
\text { treatment } \\
\text { Routine } \\
\text { treatment: not } \\
\text { specified }\end{array}$ & $\begin{array}{l}\text { Incidence of } \\
\text { death Incidence } \\
\text { of end-stage } \\
\text { renal disease } \\
\text { Incidence of } \\
\text { doubling of } \\
\text { serum creatinine }\end{array}$ \\
\hline
\end{tabular}




\begin{tabular}{|c|c|c|c|c|c|}
\hline Study & $\begin{array}{l}\text { General } \\
\text { Details }\end{array}$ & $\begin{array}{l}\text { Inclusion } \\
\text { Criteria }\end{array}$ & $\begin{array}{l}\text { Exclusion } \\
\text { Criteria }\end{array}$ & Intervention & Outcomes \\
\hline $\begin{array}{l}\text { Schulman } 2015 \\
\text { (EPPIC-2) }\end{array}$ & $\begin{array}{l}\text { Multi-center } \\
\text { Study design: } \\
\text { randomized } \\
\text { controlled trial } \\
\text { Number: } \\
\text { treatment group } \\
\text { (508), control } \\
\text { group (507) } \\
\text { Median } \\
\text { duration: } 96.3 \\
\text { weeks (treatment } \\
\text { group), } 91.6 \\
\text { weeks (control } \\
\text { group) Chronic } \\
\text { kidney disease } \\
\text { stage of subjects } \\
\text { in treatment } \\
\text { group: 3a } \\
(0.6 \%), 3 \mathrm{~b} \\
(16.6 \%), 4 \\
(66.2 \%), 5 \\
(16.6 \%) \text { Chronic } \\
\text { kidney disease } \\
\text { stage of subjects } \\
\text { in control group: } \\
3 \text { a (0.4\%), 3b } \\
(11.7 \%), 4 \\
(69.2 \%), 5 \\
(18.7 \%)\end{array}$ & $\begin{array}{l}\text { Age [?]18 years } \\
\text { Moderate to } \\
\text { severe chronic } \\
\text { kidney disease } \\
\text { Proteinuria or } \\
\text { progressive } \\
\text { decline of renal } \\
\text { function } \\
\text { Expected not to } \\
\text { require renal } \\
\text { replacement } \\
\text { therapy for } 6 \\
\text { months after } \\
\text { trial Stable } \\
\text { blood pressure in } \\
\text { the past } 3 \\
\text { months }\end{array}$ & $\begin{array}{l}\text { Uncontrolled } \\
\text { hypertension } \\
\text { Obstructive or } \\
\text { reversible kidney } \\
\text { disease } \\
\text { Nephrotic } \\
\text { syndrome (urine } \\
\text { protein/urine } \\
\text { creatinine } 6.0 \text { ) } \\
\text { Adult polycystic } \\
\text { kidney disease } \\
\text { Uncontrolled } \\
\text { arrhythmia or } \\
\text { severe } \\
\text { cardiovascular } \\
\text { disease Immuno- } \\
\text { suppressive } \\
\text { therapy within } 3 \\
\text { months } \\
\text { Accelerated or } \\
\text { malignant } \\
\text { hypertension } \\
\text { within } 6 \text { months } \\
\text { History of any of } \\
\text { the following: } \\
\text { kidney } \\
\text { transplantation, } \\
\text { malabsorption, } \\
\text { inflammatory } \\
\text { bowel disease, } \\
\text { hiatal hernia, } \\
\text { active peptic } \\
\text { ulcer, and severe } \\
\text { gastrointestinal } \\
\text { dysmotility not } \\
\text { attributable to } \\
\text { the use of a } \\
\text { phosphate } \\
\text { binder }\end{array}$ & $\begin{array}{l}\text { Treatment } \\
\text { group: AST-120 } \\
9.0 \text { g/day (ten } \\
\text { 300-mg capsules } \\
\text { thrice daily with } \\
\text { meals) + routine } \\
\text { treatment } \\
\text { Control group: } \\
\text { placebo (ten } \\
\text { 300-mg capsules } \\
\text { thrice daily with } \\
\text { meals) + routine } \\
\text { treatment } \\
\text { Routine } \\
\text { treatment: not } \\
\text { specified }\end{array}$ & $\begin{array}{l}\text { Incidence of } \\
\text { death Incidence } \\
\text { of end-stage } \\
\text { renal disease } \\
\text { Incidence of } \\
\text { doubling of } \\
\text { serum creatinine } \\
\text { Quality-of-life } \\
\text { assessments }\end{array}$ \\
\hline
\end{tabular}




\begin{tabular}{|c|c|c|c|c|c|}
\hline Study & $\begin{array}{l}\text { General } \\
\text { Details }\end{array}$ & $\begin{array}{l}\text { Inclusion } \\
\text { Criteria }\end{array}$ & $\begin{array}{l}\text { Exclusion } \\
\text { Criteria }\end{array}$ & Intervention & Outcomes \\
\hline Yorioka 2008 & $\begin{array}{l}\text { Country: Japan } \\
\text { Study design: } \\
\text { randomized } \\
\text { controlled trial } \\
\text { Number: } \\
\text { treatment group } \\
\text { (15), control } \\
\text { group (13) }\end{array}$ & $\begin{array}{l}\text { Adult patients } \\
20-80 \text { years old } \\
\text { Chronic kidney } \\
\text { disease stage } 3-4 \\
\text { Etiology of } \\
\text { chronic kidney } \\
\text { disease: chronic } \\
\text { glomerulonephri- } \\
\text { tis, diabetic } \\
\text { nephropathy, } \\
\text { nephrosclerosis }\end{array}$ & $\begin{array}{l}\text { Age }<20 \text { or }>80 \\
\text { years Other } \\
\text { underlying } \\
\text { kidney diseases }\end{array}$ & $\begin{array}{l}\text { Treatment } \\
\text { group: AST-120 } \\
6.0 \mathrm{~g} / \text { day }+ \\
\text { routine } \\
\text { treatment } \\
\text { Control group: } \\
\text { routine } \\
\text { treatment } \\
\text { Routine } \\
\text { treatment: low } \\
\text { protein diet }+ \\
\text { renin- } \\
\text { angiotensin- } \\
\text { aldosterone } \\
\text { system blocker } \\
\text { therapy }\end{array}$ & $\begin{array}{l}\text { Incidence of } \\
\text { end-stage renal } \\
\text { disease Change } \\
\text { in glomerular } \\
\text { filtration rate } \\
\text { Change on slope } \\
\text { of glomerular } \\
\text { filtration rate } \\
\text { curve }\end{array}$ \\
\hline
\end{tabular}

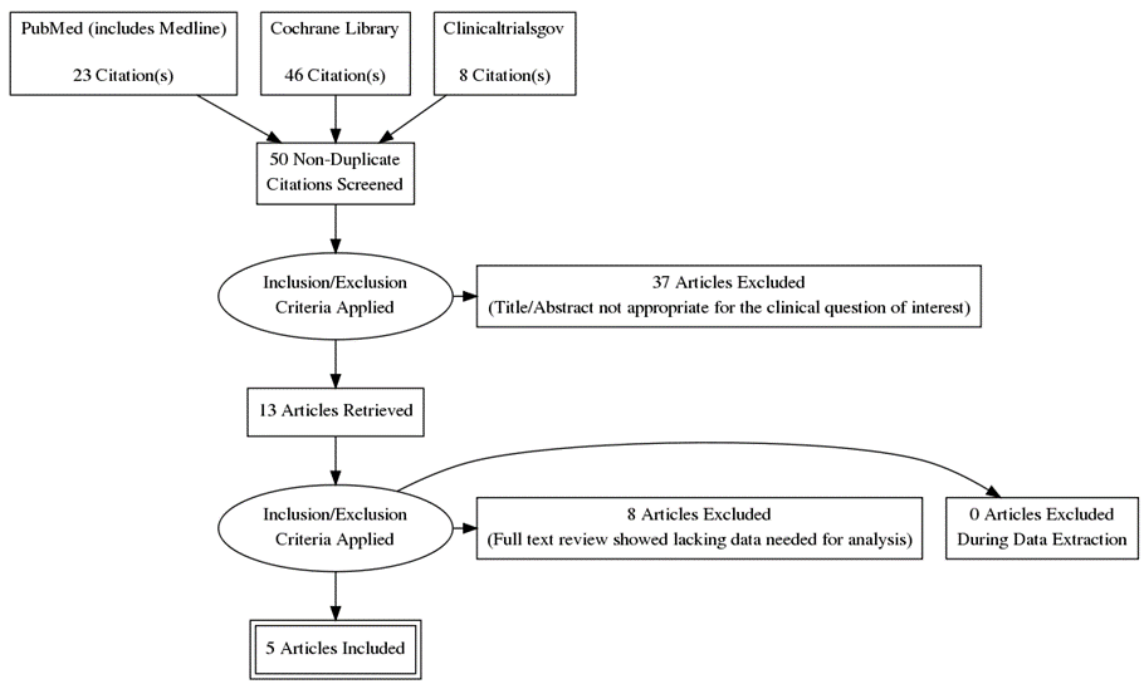



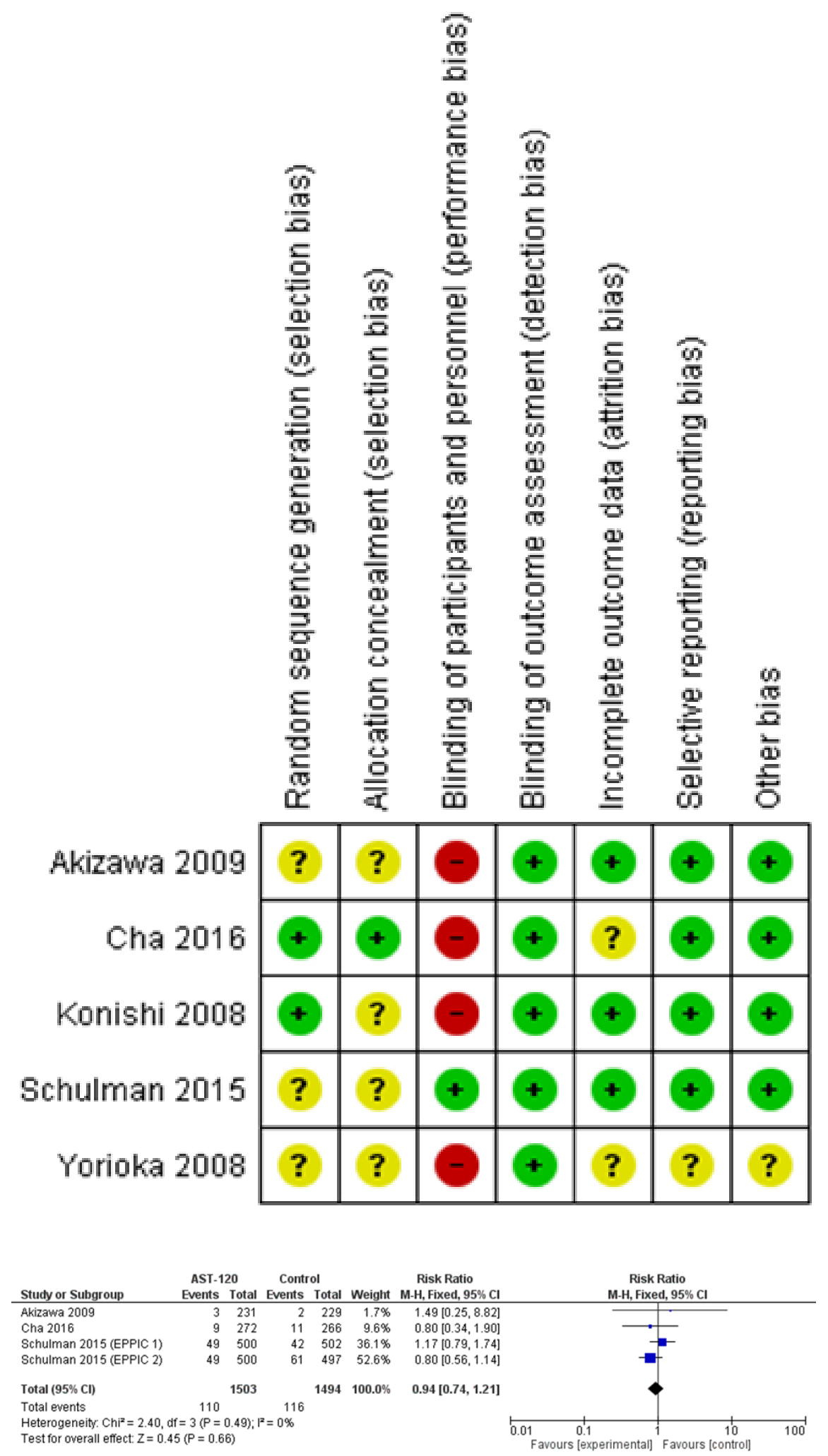


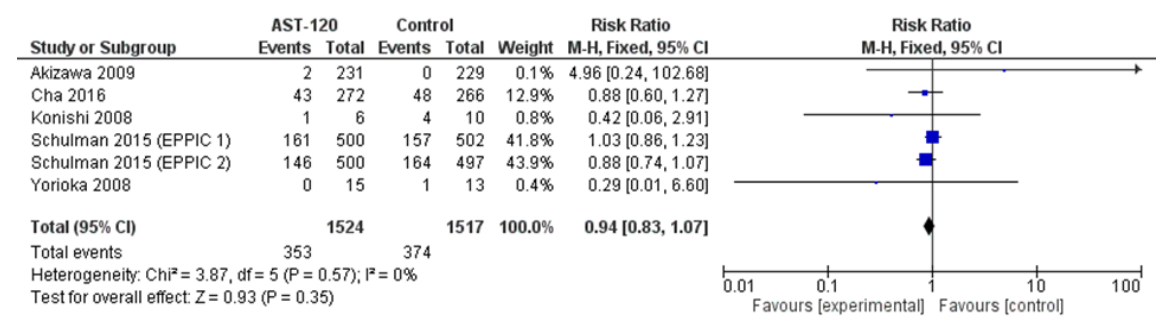

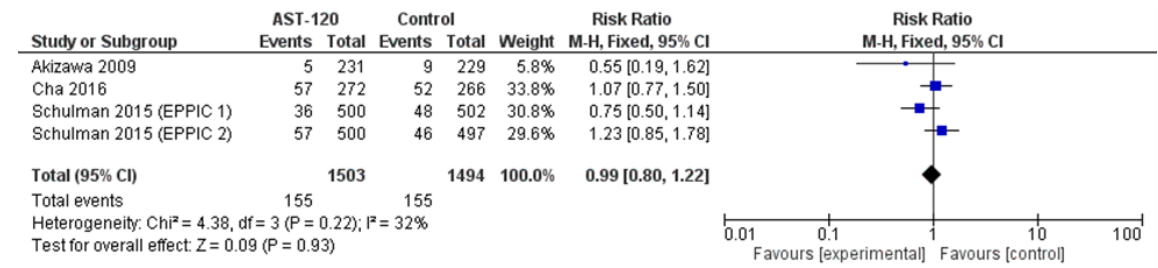

